\title{
Gambaran foto toraks pada penderita batuk kronis di Bagian/SMF Radiologi FK Unsrat/RSUP Prof. Dr. R. D. Kandou Manado periode Juli - September 2015
}

\author{
${ }^{1}$ Divertt Tamaweol \\ ${ }^{2}$ Ramli Hadji Ali \\ ${ }^{2}$ Martin L. Simanjuntak
}

\author{
${ }^{1}$ Kandidat skripsi Fakultas Kedokteran Universitas Sam Ratulangi Manado \\ ${ }^{2}$ Bagian Radiologi Fakultas Kedokteran Universitas Sam Ratulangi Manado \\ Email: divertt.tamaweol12147@gmail.com
}

\begin{abstract}
Chronic cough is defined as cough that lasts 8 weeks or more. Chronic cough itself is not a disease, but a symptom of other diseases. Chronic cough is the most common symptom that occurs among outpatients and is the main cause of morbidity which was reported by $3-40 \%$ population. Chronic cough can be caused by some diseases such as pneumonia, tuberculosis, asthma, chronic bronchitis, emphysema, and lung fibrosis. Chronic cough is closely associated with smoking habit which is one of the predisposing factors. Chest $\mathrm{x}$-ray is one of the seed examination for chronic cough because it is very helpful in diagnosing diseases especially pulmonary diseases and others that may cause chronic cough. Objective: To identify the chest x-ray imaging in chronic cough patients. Methods: This study using retrospective description data in November 2015. Sample is obtained from all the medical records of patients with radiological diagnosis chronic cough who undertook a chest X-ray examination in the Radiology Department of the Medical Faculty of Sam Ratulangi University / Prof. Dr. R. D. Kandou Central General Hospital Manado during July - September 2015. Data was collected from chest x-ray request form and the results show 178 cases of chronic cough that fit the inclusion criteria. The results showed that there was 178 cases of chronic cough based on the radiological diagnosis. The most frequent cases were chronic cough caused by pulmonary tuberculosis (97 patients; 54.49\%). Most patients were male (107 patients; $60.11 \%$ ), and the most frequent age group was 20-49 years (60 patients; 33.71\%).
\end{abstract}

Keywords: chronic cough, chest $\mathrm{x}$-ray

\begin{abstract}
Abstrak: Batuk kronik adalah batuk yang berlangsung selama 8 minggu atau lebih. Batuk kronik sendiri bukanlah penyakit, tetapi merupakan suatu gejala dari penyakit-penyakit lain. Batuk kronik merupakan gejala yang paling umum terdapat pada orang dewasa yang melakukan pengobatan rawat jalan dan penyebab utama morbiditas yang dilaporkan oleh 3$40 \%$ populasi. Batuk kronik dapat disebabkan oleh beberapa penyakit seperti pneumonia, tuberculosis, asma, bronchitis kronik, emfisema, dan fibrosis paru. Batuk kronik erat hubungannya dengan kebiasaan merokok dimana merokok merupakan salah satu faktor predisposisi. Foto toraks adalah salah satu pemeriksaan pilihan untuk batuk kronik karena sangat bermanfaat dalam mendiagnosis penyakit terutama penyakit paru dan gangguan lain yang dapat menyebabkan batuk kronik. Penelitian ini bertujuan untuk mengetahui gambaran foto toraks pada penderita batuk kronik. Penelitian ini menggunakan metode deskriptif retropektif yang dilakukan pada bulan November 2015. Sampel diambil dari semua data catatan medik pasien dengan diagnosis radiologis batuk kronik yang melakukan foto toraks di Bagian/SMF Radiologi FK Unsrat/RSUP Prof. Dr. R. D. Kandou Manado periode Juli September 2015. Data diperoleh melalui lembaran permintaan pemeriksaan foto toraks dan didapatkan sebanyak 178 kasus batuk kronik yang masuk dalam kriteria inklusi. Hasil
\end{abstract}


penelitian memperlihatkan 178 kasus batuk kronik berdasarkan diagnosis radiologis. Kasus terbanyak ialah batuk kronik akibat tuberkulosis paru sebanyak 97 orang $(54,49 \%)$, penderita terbanyak ialah laki-laki yaitu 107 orang $(60,11 \%)$, dan golongan umur terbanyak ialah 20-49 tahun yaitu 60 penderita (33,71\%).

Kata kunci: batuk kronik, foto toraks

Batuk merupakan upaya pertahanan paru terhadap berbagai rangsangan yang ada dan refleks fisiologis yang melindungi paru dari trauma mekanik, kimia dan suhu. Batuk menjadi patologis bila dirasakan sebagai gangguan. Batuk seperti itu sering merupakan tanda suatu penyakit di dalam atau diluar paru dan kadang berupa gejala awal dari suatu penyakit. Batuk merupakan gejala tersering penyakit pernapasan dan masalah yang sering kali dihadapi dokter dalam praktik sehari-hari. ${ }^{1,2}$

Batuk kronik adalah batuk yang berlangsung selama 8 minggu atau lebih. Batuk kronik sendiri bukanlah penyakit, tetapi merupakan suatu gejala dari penyakit-penyakit lain. Batuk kronik dapat menyebabkan badan menjadi lemah, dapat merusak kualitas tidur dan membuat perasaan menjadi marah dan juga frustasi. Batuk kronik merupakan gejala yang paling umum terdapat pada orang dewasa yang melakukan pengobatan rawat jalan. ${ }^{3-5}$

Batuk kronik merupakan penyebab utama morbiditas yang dilaporkan oleh 3$40 \%$ populasi. Berdasarkan survey yang dilakukan pada 11,000 pasien di Inggris bagian tenggara, batuk dilaporkan setiap hari oleh 14\% laki-laki dan 10\% perempuan. Dari survey yang dilakukan oleh European Respiratory Society terhadap 18,277 subyek dengan usia 20-48 tahun dari 16 negara di seluruh dunia, dilaporkan batuk nokturnal sebanyak 30\%, batuk produktif $10 \%$ dan batuk non produktif $10 \%$. Di Indonesia, batuk kronik pada 16,663 pasang siswa SMP bersama ibunya yang tinggal di daerah ibukota provinsi berhubungan erat dengan berada di dekat jalan raya dan perokok aktif. Dalam survey terhadap populasi, didapatkan bahwa laki-laki lebih sering mengeluhkan batuk. ${ }^{6-9}$

Batuk kronik dapat disebabkan oleh beberapa penyakit seperti pneumonia, tuberkulosis, asma, bronkitis kronik, emfisema, fibrosis paru, dan lain-lain. ${ }^{4-5}$

Batuk kronik erat hubungannya dengan kebiasaan merokok dimana merokok merupakan salah satu faktor predisposisi. Penelitian epidemiologi telah menunjukkan bahwa batuk kronik banyak berhubungan dengan kebiasaan merokok. Dua puluh lima persen dari mereka yang merokok 1/2 bungkus/hari akan mengalami batuk-batuk, sementara dari penderita yang merokok 1 bungkus per hari akan ditemukan kira-kira $50 \%$ yang batuk kronik. ${ }^{10}$

Foto toraks ialah suatu jenis pemeriksaan radiologi dengan menggunakan sinar roentgen (sinar $\mathrm{X}$ ) dimana radiograf diambil dari sudut pandang posteroanterior dan kadang juga diambil dari sudut pandang lateral dan melintang. Foto toraks dapat membantu dalam kasus batuk kronik karena sangat bermanfaat dalam mendiagnosis penyakit terutama penyakit paru dan gangguan lainnya yang dapat menyebabkan batuk kronik. Selain itu foto toraks juga bermanfaat untuk menilai kondisi sederhana seperti trauma, serta fraktur iga dan tulang belakang. ${ }^{11-13}$

Penelitian ini bertujuan untuk mengetahui gambaran foto toraks pada penderita batuk kronik di Bagian/SMF Radiologi FK UNSRAT/RSUP Prof. Dr. R.D. Kandou Manado periode Juli September 2015.

\section{METODE PENELITIAN}

Penelitian ini merupakan penelitian deskriptif retrospektif. Lokasi penelitian berada di Bagian/SMF Radiologi FK UNSRAT/RSUP Prof. Dr. R.D. Kandou Manado. Populasi penelitian ialah data catatan medik pasien batuk kronik yang melakukan foto toraks di Bagian/SMF Radiologi FK Unsrat/RSUP Prof. Dr. R. D. 
Kandou Manado tahun 2015 sedangkan sampel penelitian adalah seluruh data dari catatan medik pasien dengan diagnosis radiologis batuk kronik yang melakukan foto toraks di Bagian/SMF Radiologi FK UNSRAT/RSUP Prof. Dr. R.D. Kandou Manado periode Juli - September 2015. Alat dan bahan yang digunakan adalah catatan medik formulir permintaan pemeriksaan foto toraks. Variabel penelitian yang diteliti yaitu: jenis kelamin, umur, dan penyakit penyebab.

Cara kerja dari penelitian ini yaitu mengumpulkan data dari catatan medik penderita batuk kronik yang melakukan foto toraks di bagian Radiologi RSUP Prof. Dr. R. D. Kandou Manado periode Juli September 2015. Data kemudian diolah dan disajikan dalam bentuk tabel.

\section{HASIL PENELITIAN}

Berdasarkan penelitian yang dilakukan di Bagian/SMF Radiologi FK UNSRAT/ RSUP Prof. Dr. R. D. Kandou Manado pada penderita batuk kronik yang telah dilakukan pemeriksaan foto toraks selama periode Juli - September 2015 ditemukan 178 kasus. Berdasarkan data pada tabel 1, didapatkan bahwa jumlah penderita lakilaki lebih banyak dari perempuan dimana diperoleh 107 penderita (60,11\%) berjenis kelamin laki-laki dan 71 penderita (39,89\%) berjenis kelamin perempuan.

Tabel 1. Distribusi penderita berdasarkan jenis kelamin

\begin{tabular}{ccc}
\hline $\begin{array}{c}\text { Jenis } \\
\text { Kelamin }\end{array}$ & $\begin{array}{c}\text { Jumlah } \\
\text { Penderita }\end{array}$ & $(\%)$ \\
\hline Laki-laki & 107 & 60,11 \\
Perempuan & 71 & 39,89 \\
\hline Jumlah & 178 & 100 \\
\hline
\end{tabular}

Tabel 2 menunjukkan bahwa distribusi berdasarkan kelompok umur didapatkan kasus terbanyak yaitu 60 penderita (33,71\%) pada kelompok umur 20-49 tahun, kemudian diikuti kelompok umur > 60 tahun sebanyak 55 penderita (30,90\%), kelompok umur 50-60 tahun sebanyak 54 penderita (30,34\%), dan kelompok umur <
20 tahun sebanyak 9 penderita (5,06\%).

Tabel 2. Distribusi penderita berdasarkan kelompok umur

\begin{tabular}{ccc}
\hline Umur & $\begin{array}{c}\text { Jumlah } \\
\text { Penderita }\end{array}$ & (\%) \\
\hline$<20$ tahun & 9 & 5,06 \\
20-49 tahun & 60 & 33,71 \\
50-60 tahun & 54 & 30,34 \\
$>$ 60 tahun & 55 & 30,90 \\
\hline Jumlah & 178 & 100 \\
\hline
\end{tabular}

Tabel 3 menunjukkan bahwa dari 178 kasus, distribusi penderita batuk kronik berdasarkan penyakit penyebab menurut hasil pemeriksaan foto toraks didapatkan kasus terbanyak adalah tuberkulosis paru sebanyak 97 penderita (54,49\%), kemudian diikuti pneumonia sebanyak 47 penderita (26,40\%), emfisematous lung sebanyak 15 penderita $(8,43 \%)$, COPD/PPOK sebanyak 7 penderita (3,93\%), fibrosis paru sebanyak 5 penderita (2,81\%), bronkitis kronik sebanyak 4 penderita (2,25\%), aneurisme aorta sebanyak 2 penderita (1,12\%), dan massa mediastinum sebanyak 1 penderita $(0,56 \%)$.

Tabel 3. Distribusi penderita batuk kronik berdasarkan penyakit penyebab

\begin{tabular}{ccc}
\hline Penyakit & Jumlah & (\%) \\
Penyebab & Penderita & \\
\hline Tuberkulosis & & \\
paru & 97 & 54,49 \\
Pneumonia & 47 & 26,40 \\
Fibrosis Paru & 5 & 2,81 \\
Emfisematous & & \\
$\quad$ Lung & 15 & 8,43 \\
Aneurisme & & \\
$\quad$ Aorta & 2 & 1,12 \\
Massa & & \\
Mediastinum & 1 & 0,56 \\
Bronkitis & & \\
Kronik & 4 & 2,25 \\
COPD/PPOK & 7 & 3,93 \\
Jumlah & 178 & $100 \%$ \\
\hline \hline
\end{tabular}




\section{BAHASAN}

Pada penelitian ini didapatkan sebanyak 178 sampel dengan berbagai diagnosis radiologis yang merupakan penyebab batuk kronik di Bagian/SMF Radiologi FK UNSRAT/ RSUP Prof Dr. R. D. Kandou Manado periode Juli September 2015.

Data pada Tabel 1 menunjukkan bahwa penderita batuk kronik dengan jenis kelamin laki-laki berjumlah 107 orang $(60,11 \%)$ dan lebih banyak dibandingkan dengan penderita perempuan yang berjumlah 71 orang $(39,89 \%)$.

Hal ini sesuai dengan survey yang dilakukan European Respiratory Society terhadap 11.000 pasien di daerah Inggris bagian tenggara dimana batuk dilaporkan setiap hari oleh 14\% laki-laki dan 10\% perempuan. Hal ini biasanya dipengaruhi oleh faktor predisposisi yaitu laki-laki lebih sering merokok dibandingkan dengan perempuan. $^{8,10}$

Data pada tabel 2 menunjukkan bahwa kasus batuk kronik paling banyak terjadi pada kelompok umur 20-49 tahun yaitu sebanyak 60 penderita $(33,71 \%)$ dan paling sedikit terjadi pada kelompok umur $<20$ tahun yaitu sebanyak 9 penderita (5,06\%).

Hal ini sesuai dengan data survey European Respiratory Society terhadap 18.277 subyek dengan usia 20-48 tahun, dimana dilaporkan batuk nokturnal sebanyak $30 \%$, batuk produktif $10 \%$ dan batuk non produktif $10 \%$. Hal ini juga dipengaruhi oleh semakin banyaknya pajanan faktor resiko seperti merokok di usia seperti itu. Data dari Kepmenkes RI No 364/MENKES/SK/V/2009 juga menyatakan bahwa sekitar 75\% pasien TB, yang merupakan penyebab tersering batuk kronik adalah kelompok usia yang paling produktif secara ekonomis yaitu 15-50 tahun. ${ }^{6,14}$

Pada Tabel 3 didapatkan kasus terbanyak adalah tuberkulosis paru sebanyak 97 penderita (54,49\%), kemudian diikuti pneumonia sebanyak 47 penderita (26,40\%), emfisematous lung sebanyak 15 penderita (8,43\%), COPD/PPOK sebanyak 7 penderita (3,93\%), fibrosis paru sebanyak
5 penderita (2,81\%), bronkitis kronik sebanyak 4 penderita (2,25\%), aneurisme aorta sebanyak 2 penderita (1,12\%), dan massa mediastinum sebanyak 1 penderita $(0,56 \%)$.

Hal ini sesuai dengan fakta yang menyatakan bahwa tuberkulosis (TB) paru merupakan penyebab tersering batuk kronik selain asma dan bronkitis. Berdasarkan data dari Depkes RI 2007, di Indonesia TB merupakan masalah utama kesehatan masyarakat dimana jumlah pasien TB di Indonesia merupakan ke-3 terbanyak di dunia setelah India dan Cina dengan insidensi kasus TB BTA positif sekitar 110 per 100.000 penduduk. Data dari WHO 2012 juga menjelaskan bahwa prevalensi TB di Indonesia adalah 297 per 100.000 populasi. ${ }^{14}$

\section{SIMPULAN}

Berdasarkan hasil penelitian yang dilakukan di Bagian/SMF Radiologi FK Unsrat/RSUP Prof. Dr. R. D. Kandou Manado periode Juli - September 2015 mengenai gambaran foto toraks pada penderita batuk kronik, maka penulis dapat disimpulkan bahwa:

1. Kasus batuk kronik lebih banyak terjadi pada laki-laki dibanding perempuan

2. Penderita batuk kronik terbanyak pada golongan umur 20-49 tahun dan paling sedikit terjadi pada kelompok umur $<20$ tahun

3. Penyakit penyebab batuk kronik terbanyak berdasarkan diagnosis radiologis ialah tuberkulosis paru dan yang paling sedikit ialah massa mediastinum

\section{SARAN}

Disarankan untuk meningkatkan kelengkapan data pada lembaran permintaan dan pemeriksaan foto toraks sebaiknya lebih lengkap, karena hal tersebut sangat penting sebagai kebutuhan rumah sakit termasuk untuk menunjang penelitian selanjutnya.

\section{DAFTAR PUSTAKA}

1. Blumenthal MN. Kelainan Alergi pada 
Pasien THT. In: Effendi H, Santoso K, editors. Buku Ajar Penyakit THT Boies (6th ed). Jakarta: EGC, 1997; p. 196-8.

2. Wilson LM. Tanda dan Gejala Penting pada Penyakit Pernapasan. In: Price SA, Wilson LM, editors. Patofisiologi: Konsep Klinis Proses-Proses Penyakit (6th ed). Jakarta: EGC, 2005; p.7738.

3. Chen HH. Chronic cough. 2014 May 13 [cited 2015 Oct 8]. Available from: http://emedicine.medscape.com/articl e/1048560-overview

4. Chung KF, Pavord ID. Prevalence, pathogenesis, and causes of chronic cough. Lancet. 2008;371:1364-74.

5. Irwin RS, Madison JM. The diagnosis and treatment of cough. N Engl J Med. 2000;343:1715-21.

6. Morice AH, Fontana GA, Sovijarvi ARA, Pistolesi M, Chung KF, Widdicombe $\mathbf{J}$, et al. The diagnosis and management of chronic cough. Eur Respir J. 2004;24:482.

7. Chung KF, Widdicombe JG, Boushey HA. Cough: Causes Mechanisms and Therapy. Massachusetts: Blackwell; 2003.p.4-5.

8. Morice AH, Kastelik JA. Chronic cough in adults. Thorax. 2003;58:901-7.

9. Song WJ, Faruqi S, Klaewsongkram J, Lee SE, Chang YS. Chronic cough: an Asian perspective. Asia Pac Allergy. 2015;5:136-44.

10.McCool FD. Global physiology and pathophysiology of cough. Chest. 2006;129(1 supl:48S-53S.

11. Wilson LM. Prosedur Diagnostik pada Penyakit Pernapasan. In: Price SA, Wilson LM, editors. Patofisiologi: Konsep Klinis Proses-Proses Penyakit (6th ed). Jakarta: EGC, 2005; p.7569.

12.Patel PR. Lecture Notes: Radiologi (2nd ed). Jakarta: Erlangga, 2007; p.5-6.

13.National Institutes of Health. Cough and Chronic Cough Fact Sheet. 2010 Oct 1 [cited 2015 Oct 9]. Available from: http://www.nhlbi.nih.gov/health/healt h-topics/topics/cough

14.World Health Organization. Global Tuberculosis Report. 2012. [cited 2015 Dec 17]. Available from: http://www.who.int/iris/bitstream/978 9241564502/eng 